\title{
Economic impacts of Bovine alphaherpesvirus 1 infection in Brazil: Meta-analysis based on epidemiological indicators
}

\section{Impactos econômicos da infecção por Bovine alphaherpesvirus 1 no Brasil: Metanálise a partir de indicadores epidemiológicos}

\author{
Bruno Pajeú e Silva ${ }^{1 *}$; Breno Bezerra Aragão ${ }^{1}$; José Wilton Pinheiro Junior ${ }^{2}$
}

\section{Highlights}

A prevalence of $54.12 \%$ was identified in cattle in Brazil.

The prevalence in herds was $88.53 \%$.

The occurrence of 258,779 bovine abortions per year was estimated.

The annual impact on livestock was estimated at US\$48,402,244.00 due to abortions.

\begin{abstract}
This study aimed to conduct a systematic review to estimate the economic impact of Bovine alphaherpesvirus 1 (BoAHV1) infection in Brazil using epidemiological indicators through a meta-analysis. Specific descriptors were used to retrieve studies from the Scopus, PubMed, Biblioteca Digital Brasileira de Teses e Dissertações, and Catálogo de Teses e Dissertações da Capes databases, selecting those that met the inclusion criteria established between the years 2000 and 2020 . The selected studies were subjected to descriptive statistical analysis using prevalence data as the primary outcome with a 95\% confidence interval (Cl) with a meta-analysis of random effects and measures of heterogeneity, significance, magnitude of the effect, and measurement of publication bias. Abortion costs and estimates were calculated based on the prevalence of BoAHV1 infection in Brazil and the characteristics of the agent as viral subtypes that cause abortion, period of occurrence, average pregnancy rate, and morbidity applied to susceptible animals and animal replacement values. The results were obtained from 49 studies included for meta-analysis where a prevalence of BoAHV1 infection of $54.12 \%$ (95\% Cl: $49.07 \%-59.26 \%$ ) in the bovine population and $88.53 \%$ (95\% Cl: $82.97 \%-92.43 \%)$ was present. From the structured formula, it is estimated that 258,779 bovine abortions occur, which causes a total loss, based only on the occurrence of abortion, of US $\$ 48,402,244.00$ to the country. It is noteworthy that because of the losses caused, strict control and eradication measures need to be implemented based on the elaboration of normative

1 Doctorate in Animal Bioscience, PhD Program in Animal Bioscience, Universidade Federal Rural de Pernambuco, UFRPE, Recife, PE, Brazil. E-mail: bruno_pajeu@hotmail.com, breno.aragao100@hotmail.com

2 Prof. Dr., Department of Veterinary Medicine, UFRPE, Recife, PE, Brazil. E-mail: wiltonjrufrpe@gmail.com

* Author for correspondence
\end{abstract}

Received: Apr. 28, 2021 - Approved: July 13, 2021 
instruction that includes health education measures, vaccination, tests for traffic, and animal trade so that BoAHV1 infections do not continue to negatively impact national producers economically, productively, and socially.

Key words: Systematic review. IBR. Abortion. Cost. Prevalence.

\section{Resumo}

Objetivou-se com o presente estudo realizar uma revisão sistemática para estimar os impactos econômicos da infecção por Alfaherpesvirus Bovino 1 no Brasil a partir dos indicadores epidemiológicos por meio de uma metanálise. Foram usados descritores específicos para a recuperação de estudos a partir das bases Scopus, Pubmed, Biblioteca Digital Brasileira de Teses e Dissertações e do Catálogo de Teses e Dissertações da Capes, selecionando-se aqueles que se enquadraram nos critérios de inclusão estabelecidos entre os anos 2000 e 2020. Os estudos selecionados foram submetidos à análise estatística descritiva utilizando-se os dados de prevalência como desfecho primário com intervalo de confiança de $95 \%$, sendo realizado metanálise de efeito randômico e avaliadas as medidas de heterogeneidade, significância, magnitude do efeito e aferição do viés de publicação. Os custos e estimativas de aborto foram calculados com base na prevalência encontrada para BoAHV1 no Brasil e as características do agente como subtipos virais que provocam o aborto, período de ocorrência, taxa média de prenhez e morbidade aplicados aos animais suscetíveis e aos valores de reposição animal. Os resultados foram obtidos a partir de 49 estudos incluídos para metanálise, onde se verificou uma prevalência de BoAHV1 de 54,12\% (IC95\%: 49,07\% - 59,26\%) na população bovina e 88,53\% (IC95\%: 82,97\% - 92,43\%) para os rebanhos. A partir da fórmula estruturada, se estima que ocorram 258.779 abortos bovinos, que totalizam um prejuízo, apenas baseado na ocorrência do aborto, de US\$ 48.402.244,00 ao país. Destaca-se que em virtude dos prejuízos ocasionados, medidas de controle e erradicação mais rigorosas precisam ser implementadas a partir da elaboração de uma instrução normativa que contemple medidas de educação sanitária, vacinação, realização de exames para o trânsito e comércio de animais para que as infecções pelo BoAHV1 não continuem a impactar negativamente os produtores nacionais de forma econômica, produtiva e socialmente.

Palavras-chave: Revisão sistemática. IBR. Aborto. Custo. Prevalência.

\section{Introduction}

Changes in the eating habits of families have led to a worldwide increase in the demand for animal protein; the safest way to meet this demand is by increasing sanitary surveillance services. This will require a more vehement action due to the intensification of means of production, since the estimated loss, according to the World Organization for Animal Health (OIE), to the detriment of animal diseases is greater than $20 \%$ (World Organization for Animal Health [OIE], 2008). Regarding infectious diseases, although viral diseases cause significant losses in cattle ranching, their reproductive impact is underestimated (Wathes, Oguejiofor, Thomas, \& Cheng, 2020).

The first report of infection by Bovine alphaherpesvirus 1 (BoAHV1) in Brazil dates to the 1960s (Galvão, Doria, \& Alice, 1962/1963), 
and its isolation was carried out more than 15 years later (Alice, 1978). Since then, many studies have reported the occurrence of this agent in Brazilian cattle herds (Pituco, 1988; Lovato, Weiblen, Tobias, \& Moraes, 1995; Cerqueira et al., 2000; Poletto, Kreutz, Gonzales, \& Barcellos, 2004; J. A. Dias et al., 2008; M. S. Lima, Nogueira, Okuda, Stefano, \& Pituco, 2011; Oliveira, Lorenzetti, Alfieri, \& Lisbôa, 2015; N. P. C. Bezerra, Bezerra, Santos, Pereira, \& Silva, 2019; Haas et al., 2020). The form of presentation and severity of infections and their pathogenesis varies according to BoAHV1 virulence, in addition to the fact that the agent is able to establish latency, contributing to the maintenance of BoAHV1 infection in the herd through asymptomatic animals that spread the virus in healthy hosts (Biswas, Bandyopadhyay, Dimri, \& Patra, 2013).

Infections caused by BoAHV1 cause several clinical conditions, among which are reproductive disorders that can range from inflammatory changes in the genital tract of affected animals to the onset of respiratory, ocular, and neurological clinical conditions (Nandi, Kumar, Manohar, \& Chauhan, 2009; Graham, 2013). Once present in the herd, albeit subclinically, the infection has been associated with a decreased productive performance of affected animals (Statham, Randall, \& Archer, 2015), which makes it important for the correct implementation of prophylactic measures to determine the prevalence of BoAHV1 infection in detriment of the socioeconomic impacts that the infection can cause (Chen et al., 2018).

The economic losses attributed to BoAHV1 infection consist of weight loss, decreased milk production, fertility problems, such as endometritis and heat repetition, the birth of weak animals, and embryo and neonatal mortality (Ata, Kocamüftüoğlu, Hasircioğlu, Kale, \& Gülay, 2012; Junqueira \& Alfieri, 2006). As a result of economic impacts and damage to animal health, many European countries have been making efforts to control and eradicate BoAHV1 infections since the 1980s (Ackermann et al., 1990; Ackermann \& Engels, 2006; Hage et al., 1998).

For the institution of disease prevention and control programs, knowledge of epidemiological factors, such as prevalence data, risk factors, prophylaxis programs, and the associated cost-benefit, are essential for estimating economic impacts and evaluating the best strategy to be implemented (Thrusfield, 2005).

To demonstrate the impact of infection by various reproductive infectious agents in cattle raising, several studies have been conducted worldwide (Statham et al., 2015; Bennett, 2003; Macías-Rioseco et al., 2020; Ran et al., 2019; Reichel, Ayanegui-Alcérrea, Gondim, \& Ellis, 2013; Sayers, 2017; Wathes et al., 2020) to warn about the damage caused by themand theimportance ofveterinaryattention services in promoting animal health and improving the quality of life of the population. Considering the economic, reproductive, and social impacts associated with abortion caused by infectious reproductive diseases, adding to the fact that BoAHV1 is an abortive agent widely disseminated in national herds and does not present a sanitary contingency norm, this systematic review aimed to calculate the prevalence of BoAHV1 infection in Brazil and estimate the direct losses associated with the occurrence of abortion in bovine species. 


\section{Material and Methods}

\section{Study design}

This study consists of a systematic review aimed to synthesize BoAHV1 infection prevalence data in cattle in Brazil and analyze, through meta-analysis, the quantitative data from manuscripts available in selected databases and from the gray literature (theses, dissertations, and reference lists) to define the cost of abortion in cattle. The study was conducted following the methodological recommendations of the Preferred Reporting Items for Systematic Reviews and MetaAnalyses (PRISMA) (Moher, Liberati, Tetzlaff, \& Altman, 2009).

\section{Databases and search strategy}

For the research on the subject, the combined search terms were defined for each of the databases using different search strategies, as the different databases use different search algorithms, requiring different combinations of the main indexing terms of the studied topic. In addition, a survey of studies was conducted during the fourth quarter of 2020.

For Scopus, the following descriptors were used: "( ALL ("Incidence") OR ALL ( "Prevalence") OR ALL ("occurrence") OR ALL ("Epidemiology") OR ALL ( "Prevalência") OR ALL ("occurrência") OR ALL ("incidência" ) OR ALL ("epidemiologia")) AND ( ALL ( "Brazil") OR ALL ("Brasil")) AND (( TITLEABS-KEY ("Herpesvirus" ) OR TITLE-ABSKEY ("Alfaherpesvirus") OR TITLE-ABS-KEY ( "Alphaherpesvirus")) AND ( TITLE-ABS-KEY
( "bovine" ) OR TITLE-ABS-KEY ( "Cattle" ) OR TITLE-ABS-KEY ("bovino" ) ) ) OR ( TITLEABS-KEY ( "BoHV-1" OR "BoHV1" OR "BHV1" OR "HVB-1" ) )." For PubMed, the following were used: "("Incidence" OR "Prevalence" OR "occurrence" OR "Epidemiology" OR "incidência" OR "prevalência" OR "Ocorrência" OR "epidemiologia") AND ("Brazil" OR "Brasil") AND ((("Herpesvirus" OR "alfaherpesvirus" OR "alphaherpesvirus") AND (("bovine" OR "Cattle" OR "bovino")) OR ("BoHV-1" OR "BoHV1" OR "BHV-1" OR "HVB-1")))".

For the recovery of theses and dissertations, in the domain of the Biblioteca Digital Brasileira de Teses e Dissertações, the following combination was used: "(Todos os campos: Incidence OR Prevalence OR Occurrence OR Epidemiology OR prevalência OR ocorrência OR incidência OR Epidemiologia OR sorológico OR serological OR soroprevalência OR Seroprevalence E Todos os campos: Herpesvirus OR alfaherpesvirus ORalphaherpesvirus ORBoHV-1 ORBoHV1 OR BHV-1 OR HVB-1 E Todos os campos:bovine OR Cattle OR bovinos OR bovino)". In addition, for the Catálogo de Teses e Dissertações Capes, the following was used: "BoHV-1 OR herpesvirus AND bovino AND prevalência OR ocorrência OR incidência OR Epidemiologia OR soroprevalência".

\section{Eligibility criteria}

The inclusion criteria were observational prevalence studies as designed or that point to the occurrence, through direct and/or indirect diagnostic methods in cattle in Brazil, of BoAHV1 infection as part of their results. The types of publications 
included consisted of full articles, "short communication" articles, abstracts presented at conferences, dissertations, and theses. No restrictions were placed on the language of the returned studies.

Was excluded manuscripts that did not discriminate the occurrence of BoAHV1 infection and those in the form of observational studies, clinical studies, studies with species other than cattle, studies that did not focus on the research of the agent of interest or the disease caused by it, studies conducted outside Brazil, studies that showed bias, such as those conducted in herds known to be positive, and those that investigated the presence of the agent through the analysis of clinical samples involving its isolation. After recovering the manuscripts, those published between 2000 and 2020 were selected.

\section{Selection of studies and data extraction}

The selection of studies was carried out independently by two different researchers, where the differences were decided by consensus between the parties. The research was carried out in four stages: identification, selection, eligibility, and inclusion criteria.

The first step consisted of registering the total number of articles returned from the terms defined to perform the searches, excluding manuscripts in duplicate. In the second stage, the titles of the articles were read, excluding those that did not cover the study area. The third step consisted of reading the abstracts of articles selected from the titles selected for reading those with information of potential interest about the occurrence of BoAHV1 infections in cattle in Brazil. Finally, the manuscripts that presented prevalence data were read in full in the fourth stage. Thereafter, those that did not present relevant information to compose the study were excluded, and the manuscripts of interest were included for analysis from the reference lists of the selected studies.

Additionally, bibliographic reference lists of selected studies were scrutinized after the fourth stage to have great coverage of the included manuscripts since not all studies were necessarily indexed in the selected databases.

\section{Statistical analysis}

Qualitative data were analyzed using descriptive statistics, using an absolute and relative distribution of positive cases for BoAHV1 infection, using raw prevalence data as the primary outcome with a $95 \%$ confidence interval (CI). To calculate the prevalence, the selected articles were subjected to a random model meta-analysis. Heterogeneity was assessed using Cochran's $Q$ test, represented by the chi-square $(\chi 2)$ test, with a significance of $P<0.10$, and its magnitude measured by the I-square (I2) test (Deeks, Higgins, \& Altman, 2019).

To check the consistency of the data from the studies selected for this systematic review, an analysis of publication bias was performed using a funnel chart. In this model, Egger's regression test was applied to assess whether the estimation of the effects presented bias or not. 
Calculation of the cost of abortion owing to BoAHV1infection

The cost of abortion owing to BoAHV1 infection in Brazil was calculated by taking as reference parameters the number of animals at risk $(n(v+n o v))$, the average pregnancy rate in the herd (Pr), the prevalence of the agent $(\mathrm{Pv})$, the morbidity rate $(\mathrm{Mb})$, the period of its occurrence to the detriment of the researched agent (PS), the viral subtypes of BoAHV1 (SV), and the abortion cost incurred calculated by the replacement cost of a pregnant cow minus the cost of a dry cow, adapted according to the proposed model Reichel et al. (2013). To do so, it was first necessary to calculate the number of abortions attributed to BoAHV1 infection (NBoAHV1) and then calculate the cost of abortion per BoAHV1 infection in Brazil according to the following formula:

Economic impact $\times$ NBoAHV1 $=(n(v+n o v)) \times$

$$
\mathrm{Pr} \times \mathrm{PV} \times \mathrm{Mb} \times \mathrm{PS} \times \mathrm{SV}
$$

\section{Results and Discussion}

The manuscript's scrutiny process is shown in Figure 1. The retrieved manuscripts were derived from databases of scientific articles and, like gray literature, from theses and dissertation deposit banks based on the descriptor terms. From the databases of scientific articles, 40 studies were retrieved from PubMed and 327 from Scopus, with the intersections of searches excluded by duplication (35), totaling 332 retrieved articles. Regarding the gray literature between theses and dissertations, 94 manuscripts from the Biblioteca Digital Brasileira de Teses e Dissertações (BDTD) and 35 from the Catálogo de Teses e Dissertações da Capes were retrieved. Excluding duplicate texts (17) resulted in a total of 112 manuscripts: 43 theses and 69 dissertations, which were added to the different databases, resulting in 444 manuscripts retrieved in total in the identification phase of the study.

In the selection stage, from the total identified manuscripts, 383 (295 articles and 88 theses and dissertations) were excluded by reading the titles, resulting in 61 manuscripts selected for reading the abstracts, 10 of which were excluded after reading the same. In the next step, eligibility, 51 manuscripts were read in full, of which 20 were excluded after the complete reading of the texts. Some studies were excluded at this stage because of the redundancy of information; only those published as scientific articles from research at the master's or doctoral levels were considered, with postgraduate manuscripts being deprecated to manuscripts published in journals.

Finally, in the inclusion stage, all 31 carefully selected studies had their reference lists scrutinized to include in the analysis of other manuscripts not covered by the search descriptors. Of these 31 studies, 18 (58.06\%) were scientific articles, 5 (16.12\%) were theses, and 8 (25.80\%) were dissertations. After reading the lists, another 18 studies, all in the form of scientific articles, were included in the systematic review, totaling 49 studies covering an interval of published works from 2000 to 2020, as listed in Table 1. 


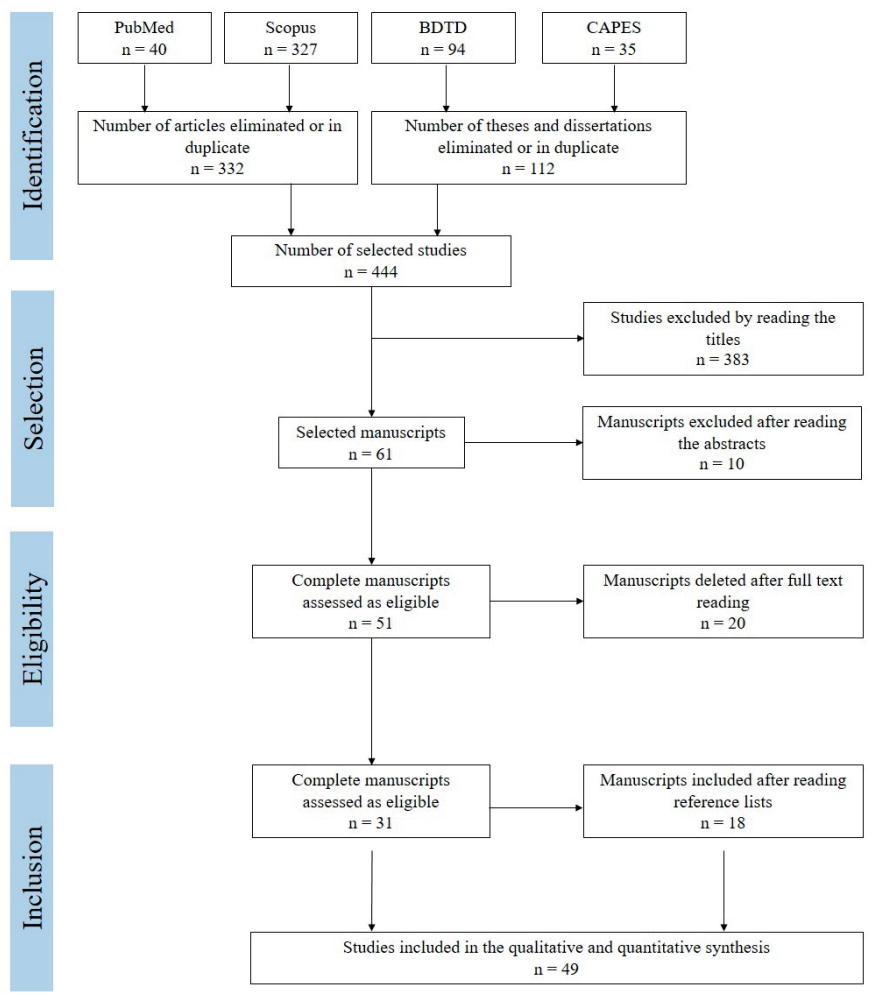

Figure 1. Study selection flowchart for inclusion in the systematic review.

\section{Table 1}

\section{Number of isolated bacterial species analyzed per year}

\begin{tabular}{|c|c|c|c|c|c|c|c|c|}
\hline \multirow{2}{*}{ Authors } & \multirow{2}{*}{ Region } & \multirow{2}{*}{ State } & \multicolumn{3}{|c|}{ Animal population } & \multicolumn{3}{|c|}{ Properties } \\
\hline & & & Cattle & Positives & $\%$ & Herds & Positives & $\%$ \\
\hline Okuda et al. (2006) & $\mathrm{N}$ & RO & 1988 & 1715 & 86.26 & 85 & 85 & 100 \\
\hline $\begin{array}{l}\text { Arruda, Silva, Aragão, Castro and Gomes } \\
\text { (2019) }\end{array}$ & $\mathrm{N}$ & $A C$ & 180 & 110 & 61.11 & & & \\
\hline Cerqueira et al. (2000) & NE & $\mathrm{BA}$ & 558 & 314 & 56.27 & 15 & 13 & 86.66 \\
\hline Matos (2004) & NE & $\mathrm{BA}$ & 764 & 145 & 18.97 & 13 & 13 & 100 \\
\hline Thompson et al. (2006) & NE & PB & 2343 & 1093 & 46.6 & 72 & 72 & 100 \\
\hline $\begin{array}{l}\text { D. C. Bezerra, Chaves, Sousa, Santos and } \\
\text { Pereira (2012) }\end{array}$ & NE & MA & 920 & 656 & 71.3 & 92 & 92 & 100 \\
\hline $\begin{array}{l}\text { Sousa, Bezerra, Chaves, Santos and Pereira } \\
\text { (2013) }\end{array}$ & NE & MA & 160 & 108 & 67.5 & 4 & 4 & 100 \\
\hline Freitas et al. (2014) & NE & MA & 1104 & 698 & 63.23 & 48 & 48 & 100 \\
\hline F. S. Silva et al. (2015) & NE & PE & 380 & 302 & 79.5 & 20 & 20 & 100 \\
\hline Freitas (2016) & NE & MA & 2455 & 753 & 30.67 & 86 & 67 & 77.91 \\
\hline F. A. B. Lima (2017) & NE & MA & 364 & 313 & 85.96 & & & \\
\hline L. G. Fernandes et al. (2019a) & NE & PB & 2443 & 1584 & 64.8 & 478 & 418 & 87.4 \\
\hline N. P. C. Bezerra et al. (2019) & NE & MA & 160 & 109 & 68.12 & 16 & 16 & 100 \\
\hline
\end{tabular}


contuation...

\begin{tabular}{|c|c|c|c|c|c|c|c|c|}
\hline B. P. Silva et al. (2019) & NE & PE & 356 & 188 & 52.8 & 18 & 18 & 100 \\
\hline $\begin{array}{l}\text { Vieira, Brito, Souza, Alfaia and Linhares } \\
\text { (2003) }\end{array}$ & $\mathrm{CO}$ & GO & 790 & 656 & 83.03 & 90 & 87 & 96.66 \\
\hline A. C. V. C. Barbosa, Brito and Alfaia (2005) & $\mathrm{CO}$ & GO & 6932 & 3596 & 51.87 & 894 & 881 & 98.54 \\
\hline Tomich et al. (2009) & $\mathrm{CO}$ & MS & 352 & 179 & 50.85 & 4 & 4 & 100 \\
\hline Afonso et al. (2010) & $\mathrm{CO}$ & $\mathrm{GO}$ & 660 & 558 & 84.54 & & & \\
\hline Melo et al. (2002) & SE & MG & 997 & 318 & 31.89 & & & \\
\hline Melo, Leite, Lobato and Leite (2004) & SE & MG & 476 & 162 & 34 & 15 & 13 & 86.66 \\
\hline Junqueira, Freitas, Alfieri and Alfieri (2006) & SE & SP & 208 & 142 & 68.26 & & & \\
\hline $\begin{array}{l}\text { Mineo, Alenius, Näslund, Montassier and } \\
\text { Björkman (2006) }\end{array}$ & SE & MG & 230 & 172 & 74.78 & 2 & 2 & 100 \\
\hline Mendes et al. (2009) & SE & MG & 126 & 101 & 80.15 & & & \\
\hline Alexandrino et al. (2011) & SE & MG;SP & 278 & 152 & 54.67 & 5 & 5 & 100 \\
\hline E. C. M. Pereira (2011) & SE & MG & 140 & 117 & 83.57 & & & \\
\hline M. C. O. P. Silva (2011) & SE & SP & 6902 & 4856 & 70.35 & 1073 & & \\
\hline $\begin{array}{l}\text { J. A. Dias, Alfieri, Ferreira-Neto, Gonçalves } \\
\text { and Müller (2013) }\end{array}$ & SE & PR & 14803 & 7125 & 59 & 2018 & 1481 & 71.38 \\
\hline Santos et al. (2014) & SE & ES & 1161 & 775 & 66.75 & 59 & 59 & 100 \\
\hline V. M. Barbosa et al. (2019) & SE & MG & 264 & 165 & 62.5 & 20 & & \\
\hline Queiroz-Castro et al. (2019) & SE & MG & 75 & 41 & 54.7 & & & \\
\hline Haas et al. (2020) & SE & MG & 476 & 231 & 48.6 & 46 & 45 & 97.5 \\
\hline Médici, Alfieri and Alfieri (2000) & S & PR & 1235 & 540 & 43.72 & 81 & 75 & 92.59 \\
\hline Poletto et al. (2004) & S & RS & 204 & 67 & 32.84 & 28 & 26 & 92.85 \\
\hline Quincozes (2005) & S & RS & 1734 & 540 & 31.14 & 85 & 72 & 84.7 \\
\hline M. M. Dias (2006) & S & RS & 1516 & 443 & 29.22 & 1 & & \\
\hline J. A. Dias et al. (2008) & $S$ & PR & 1930 & & & 295 & 190 & 64.41 \\
\hline Frandoloso et al. (2008) & S & RS & 765 & & & 26 & 15 & 57.69 \\
\hline Campos et al. (2009) & S & RS & 200 & 144 & 72 & & & \\
\hline Holz et al. (2009) & S & RS & 2200 & 538 & 24.45 & 390 & & \\
\hline Fino (2011) & S & SC & 309 & 84 & 27.18 & 6 & 6 & 100 \\
\hline Miranda (2012) & S & RS & & & & 269 & 75 & 27.88 \\
\hline Piovesan et al. (2013) & S & RS & 2794 & 1654 & 59.19 & 157 & & \\
\hline Sponchiado (2014) & S & PR & 714 & 159 & 22.3 & 26 & 17 & 65.3 \\
\hline Becker et al. (2015) & S & RS & 1224 & 299 & 24.42 & 93 & & \\
\hline Evers (2015) & S & PR & 363 & 216 & 59.5 & 32 & 30 & 93.8 \\
\hline Oliveira et al. (2015) & S & PR & 400 & 70 & 17.5 & 90 & 35 & 38.9 \\
\hline Pasqualotto, Sehnem and Winck (2015) & S & SC & 842 & 482 & 57.54 & 195 & & \\
\hline Zardo (2017) & S & RS & 258 & 24 & 9.3 & & & \\
\hline M. S. Lima et al. (2011) & BR & $\begin{array}{c}21 \\
\text { states }\end{array}$ & 4460 & 3079 & 69.03 & 317 & 250 & 78.86 \\
\hline
\end{tabular}

Abbreviations: N: North; NE: Northeast; CO: Middle West; SE: Southeast; S: South, BR: Brazil; RO: Rondônia; AC: Acre; BA: Bahia; PB: Paraíba; MA: Maranhão: PE: Pernambuco; GO: Goiás; MS: Mato Grosso do Sul; MG: Minas Gerais; SP: São Paulo; PR: Paraná; ES: Espíruto Santo; RS: Rio Grande do Sul; SC: Santa Catarina. 
To calculate the prevalence, 67,498 animals and 7,294 herds were included in the analysis. The analysis of the included studies revealed a significant heterogeneity of the studies using the $Q$ test $(P<0.001$ and $\left.\mathrm{I}^{2}=99.32 \%\right)$ to calculate the prevalence per animal, with similar values being found to calculate the prevalence of herds $(P<0.001$ and $\left.\mathrm{I}^{2}=94.47 \%\right)$. The results of asymmetries between the studies for different inferences, population, and herds, are represented in Figure 2 and Figure 3, respectively. The Egger test indicated no bias in the distribution of prevalence studies for the population of cattle $(P>0.05)$ but indicated the presence of bias for the studies among herds $(P<0.05)$.

Funnel Plot of Standard Error by Logit event rate

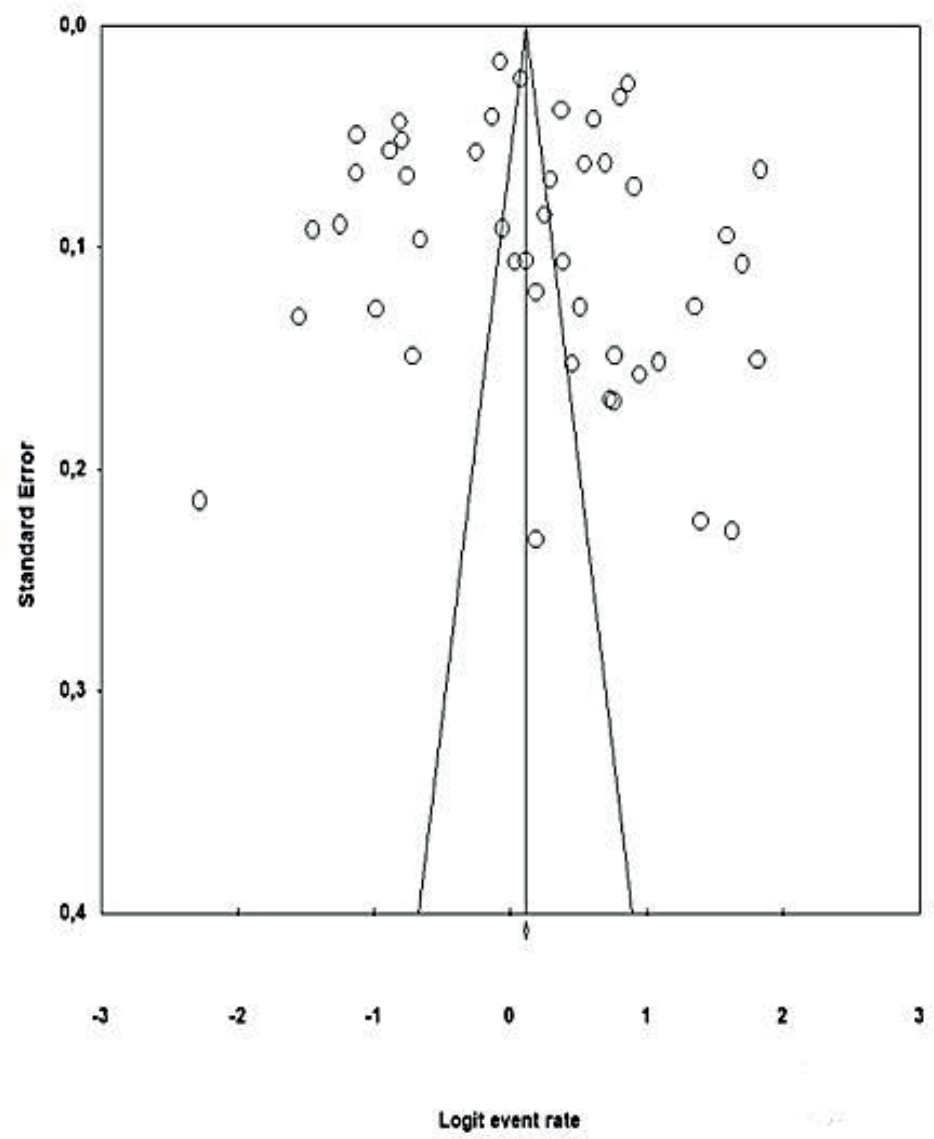

Figure 2. Funnel graph showing the asymmetric distribution of the prevalence studies of Bovine alphaherpesvirus 1 infection among the bovine population in Brazil.

The meta-analysis performed for the studies included in the systematic review identified a pooled prevalence through the random model for cattle and herds, as shown in Figure 4 and Figure 5, respectively, of $54.21 \%$ (95\% $\mathrm{Cl}: 49.07 \%$ - 59.26\%) and $88.53 \%$ (95\% Cl: $82.97-92.43 \%)$, respectively, both with significant heterogeneity $(P<0.001)$. 
Funnel Plot of Standard Error by Logit event rate

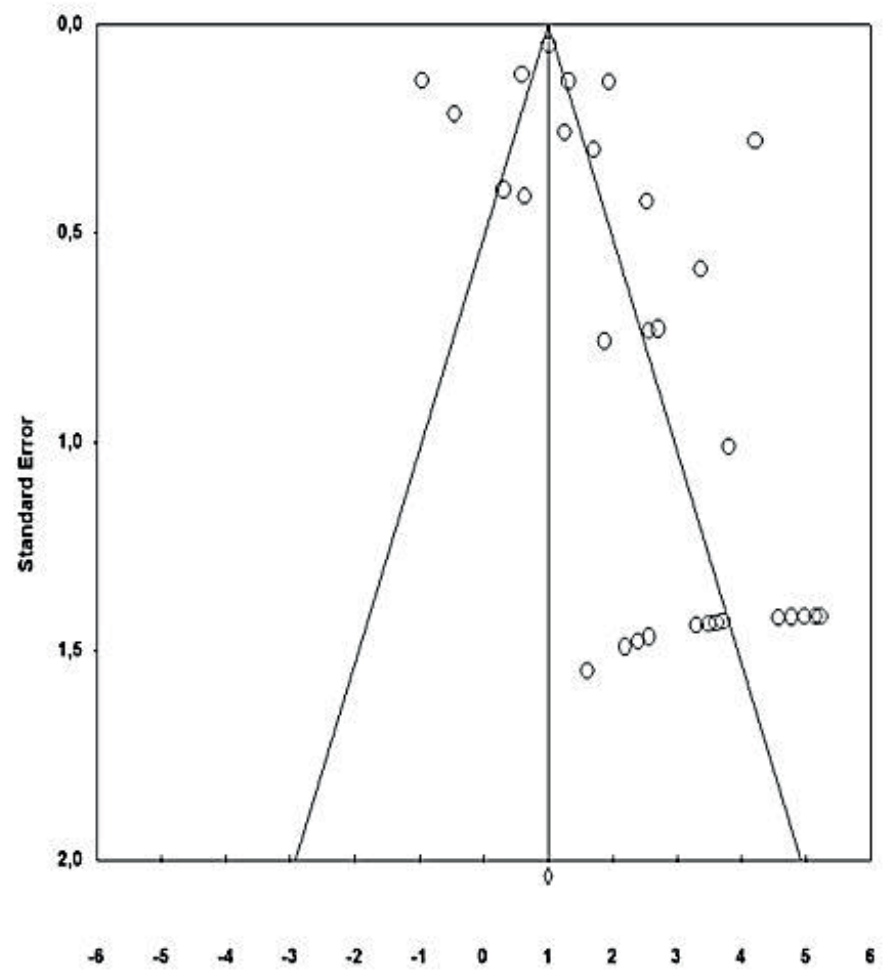

Logit event rate

Figure 3. Funnel graph showing the asymmetric distribution of studies on the prevalence of Bovine alphaherpesvirus 1 infection among cattle herds in Brazil.

Based on the data from the studies included in the meta-analysis and verifying the prevalence of $54.21 \%$, this value was applied to the modified formula of Reichel et al. (2013) to calculate the direct losses caused by abortions owing to BoAHV1 infections in cattle in Brazil. The number of female bovines of reproductive age $(\mathrm{n}(\mathrm{v}+\mathrm{nov}))$ corresponded to, according to the Instituto Brasileiro de Geografia e Estatística [IBGE] (2017), 59,670,476 heads; an average $\operatorname{Pr}$ of $60 \%$ (Vaz \& Lobato, 2010; P. A. C. Pereira et al., 2013; Rosa et al., 2017; L. A. M. Fernandes et al., 2019b; E. T. N. Pereira, Freitas, Cordeiro, Silva, \& Figueiredo, 2020) was considered based on the national literature; the Pv presented here; the $\mathrm{Mb}$ that, according to Constable, Hinchcliff, Done e Grünberg (2021), corresponded to a range that varied from 8 to $30 \%$, being used the minimum value of $8 \%$ or 0.08 ; the PS considered only the final third of pregnancy (1/4 - considering the months of susceptibility during a year); and the SV of BoAHV1 that caused abortion (2/3) according to Flores (2017). Thus, the number of abortions attributed to BoAHV1 infections could be determined using the following equation:

$$
\begin{gathered}
\text { NBoAHV1 }=(n(v+n o v)) \times P r \times P v \times M b \times P S \times \\
S V=258,779
\end{gathered}
$$




\begin{tabular}{|c|c|c|c|c|c|c|c|c|}
\hline \multirow[t]{2}{*}{ Study name } & \multirow[b]{3}{*}{ Blank } & \multirow{2}{*}{\multicolumn{5}{|c|}{$\begin{array}{l}\text { Event Lower Upper } \\
\text { rate limit limit Z-Valuep-Value }\end{array}$}} & \multirow[b]{2}{*}{ Total } & \multirow[b]{2}{*}{$\begin{array}{r}\text { Relative } \\
\text { weight }\end{array}$} \\
\hline & & & & & & & & \\
\hline Cerqueira et al., 2000 & & 0,563 & 0,521 & 0,603 & 2,955 & 0,003 & $314 / 558$ & 2,20 \\
\hline Médice; Alfieri; Alfieri, 2000 & Blank & 0,437 & 0,410 & 0.465 & $-4,399$ & 0.000 & $540 / 1235$ & 2,22 \\
\hline Melo et al., 2002 & Blank & 0,319 & 0,291 & 0,349 & $-11,163$ & 0,000 & $318 / 997$ & 2,21 \\
\hline Vieira et al., 2003 & Blank & 0.830 & 0,803 & 0,855 & 16,754 & 0,000 & $656 / 790$ & 2,19 \\
\hline Melo et al., 2004 & Blank & 0,340 & 0,299 & 0,384 & $-6,841$ & 0,000 & $162 / 476$ & 2,19 \\
\hline Matos, 2004 & Blank & 0,190 & 0,164 & 0,219 & $-15,731$ & 0,000 & $145 / 764$ & 2,19 \\
\hline Poletto et al., 2004 & Blank & 0,328 & 0,267 & 0,396 & $-4,798$ & 0,000 & $67 / 204$ & 2,14 \\
\hline Quincozes, 2005 & Blank & 0,311 & 0,290 & 0,334 & $-15,301$ & 0,000 & $540 / 1734$ & 2,22 \\
\hline Barbosa; Brito; Alfaia, 2005 & Blank & 0,519 & 0,507 & 0,531 & 3,122 & 0,002 & $3596 / 6932$ & 2,23 \\
\hline Thompson et al., 2006 & Blank & 0,466 & 0,446 & 0,487 & $-3,241$ & 0,001 & $1093 / 2343$ & 2,22 \\
\hline Mineo et al., 2006 & Blank & 0,748 & 0,688 & 0,800 & 7,159 & 0,000 & $172 / 230$ & 2,13 \\
\hline Dias, 2006 & Blank & 0,292 & 0,270 & 0,316 & $-15,665$ & 0,000 & $443 / 1516$ & 2,22 \\
\hline Okuda et al., 2006 & Blank & 0,863 & 0,847 & 0,877 & 28,202 & 0,000 & $1715 / 1988$ & 2,21 \\
\hline Junqueira et al., 2006 & Blank & 0,683 & 0,616 & 0,742 & 5,143 & 0,000 & $142 / 208$ & 2,14 \\
\hline Tomich et al., 2009 & Blank & 0,509 & 0,456 & 0,560 & 0,320 & 0,749 & $179 / 352$ & 2,18 \\
\hline Holz et al., 2009 & Blank & 0,245 & 0,227 & 0,263 & $-22,739$ & 0,000 & $538 / 2200$ & 2,22 \\
\hline Campos et al., 2009 & Blank & 0,720 & 0,654 & 0,778 & 5,997 & 0,000 & $144 / 200$ & 2,13 \\
\hline Mendes et al., 2009 & Blank & 0,802 & 0,723 & 0,862 & 6,250 & 0,000 & $101 / 126$ & 2,03 \\
\hline Afonso et al., 2010 & Blank & 0,845 & 0,816 & 0,871 & 15,781 & 0,000 & $558 / 660$ & 2,18 \\
\hline Fino, 2011 & Blank & 0,272 & 0,225 & 0,324 & $-7,706$ & 0,000 & $84 / 309$ & 2,16 \\
\hline Pereira, 2011 & Blank & 0.836 & 0,765 & 0.888 & 7,132 & 0,000 & $117 / 140$ & 2,02 \\
\hline Silva, 2011 & Blank & 0,704 & 0,693 & 0,714 & 32,793 & 0,000 & $4856 / 6902$ & 2,23 \\
\hline Alexandrino et al., 2011 & Blank & 0,547 & 0,488 & 0,604 & 1,557 & 0,119 & 278 & 2,17 \\
\hline$t$ al., 2011 & Blank & 0,6 & 0,677 & 0,704 & 24,757 & 0,000 & $/ 4460$ & 2,23 \\
\hline Bezerra et al., 2012 & Blank & 0,7 & 0,683 & 0,741 & 12,488 & 0,000 & 920 & 2,21 \\
\hline Sousa et al., 2013 & Blank & 0,675 & 0,599 & 0,743 & 4,330 & 0,000 & $108 / 160$ & 2,11 \\
\hline Dias et al., 2013 & Blank & 0,481 & 0,473 & 0,489 & $-4,544$ & 0,000 & $7125 / 14803$ & 32,23 \\
\hline Piovesan et al., 2013 & Blank & 0,592 & 0,574 & 0,610 & 9,668 & 0,000 & $1654 / 2794$ & 2,23 \\
\hline Freitas et al. 2014 & Blank & 0,632 & 0,603 & 0,660 & 8,682 & 0,000 & $698 / 1104$ & 2,21 \\
\hline Santos et al., 2014 & Blank & 0,668 & 0,640 & 0,694 & 11,189 & 0,000 & $775 / 1161$ & 2,21 \\
\hline Silva, 2014 & Blank & 0,7 & 0.751 & 0.832 & 10,658 & 0.000 & $302 / 380$ & 2,16 \\
\hline Sponchiado, 2014 & Blank & 0,223 & 0,194 & 0,255 & $-13,897$ & 0,000 & $159 / 714$ & 2,20 \\
\hline Oliveira et al., 2015 & Blank & 0,175 & 0,141 & 0,215 & $-11,784$ & 0,000 & $70 / 400$ & 2,16 \\
\hline Evers, 2015 & Blank & 0,595 & 0,544 & 0,644 & 3,599 & 0,000 & $216 / 363$ & 2,18 \\
\hline Pasqualotto et al., 2015 & Blank & 0,572 & 0,539 & 0,605 & 4,190 & 0,000 & $482 / 842$ & 2,21 \\
\hline Becker et al., 2015 & Blank & 0,244 & 0,221 & 0,269 & $-16,976$ & 0,000 & $299 / 1224$ & 2,21 \\
\hline Freitas, 2016 & Blank & 0,307 & 0,289 & 0,325 & $-18,633$ & 0,000 & $753 / 2455$ & 2,22 \\
\hline Lima, 2017 & Blank & 0,860 & 0,820 & 0,892 & 12,015 & 0,000 & $313 / 364$ & 2,13 \\
\hline Zardo, 2017 & Blank & 0,093 & 0,063 & 0,135 & $-10,625$ & 0,000 & $24 / 258$ & 2,04 \\
\hline Barbosa et al., 2019 & Blank & 0,625 & 0,565 & 0,681 & 4,018 & 0,000 & $165 / 264$ & 2,16 \\
\hline Silva et al. 2019 & Blank & 0,528 & 0,476 & 0.579 & 1,059 & 0,289 & $188 / 356$ & 2,18 \\
\hline Queiroz-Castro et al., 2019 & Blank & 0,547 & 0,434 & 0,655 & 0,807 & 0,420 & $41 / 75$ & 2,01 \\
\hline Fernandes et al 2019 & Blank & 0648 & 0.629 & 0.667 & 14442 & 0,000 & $1584 / 2443$ & 222 \\
\hline Bezerra et al. 2019 & Blank & 0,681 & 0,605 & 0,749 & 4,477 & 0,000 & $109 / 160$ & 2,11 \\
\hline Arruda et al. 2019 & Blank & 0.611 & 0,538 & 0,680 & 2,956 & 0,003 & $110 / 180$ & 2,13 \\
\hline Haas et al., 2020 & Blank & 35 & 0,441 & 0,530 & $-0,642$ & 0,521 & $231 / 476$ & 2,19 \\
\hline & & & 0,491 & 0,593 & 1,609 & 0,108 & & \\
\hline
\end{tabular}

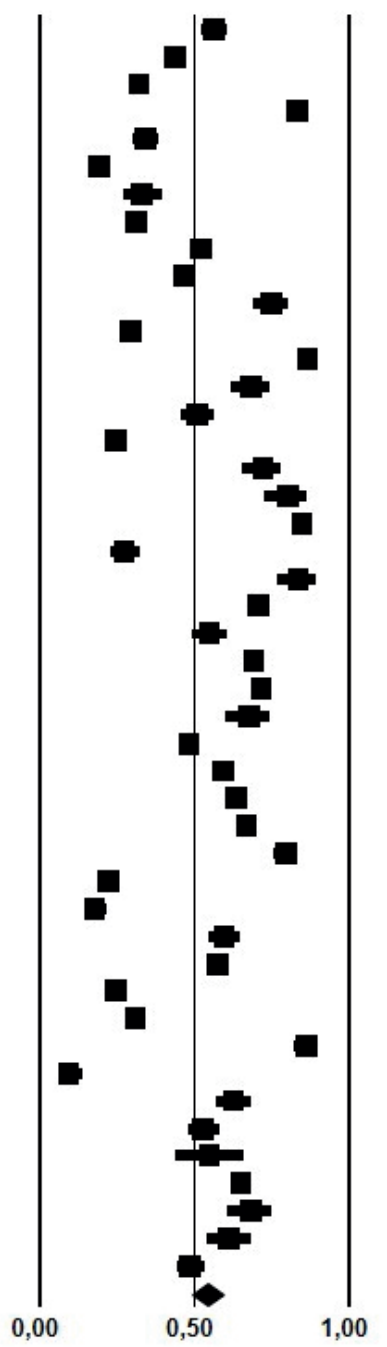

Figure 4. Prevalence of Bovine alphaherpesvirus 1 infection in the bovine population in Brazil. 


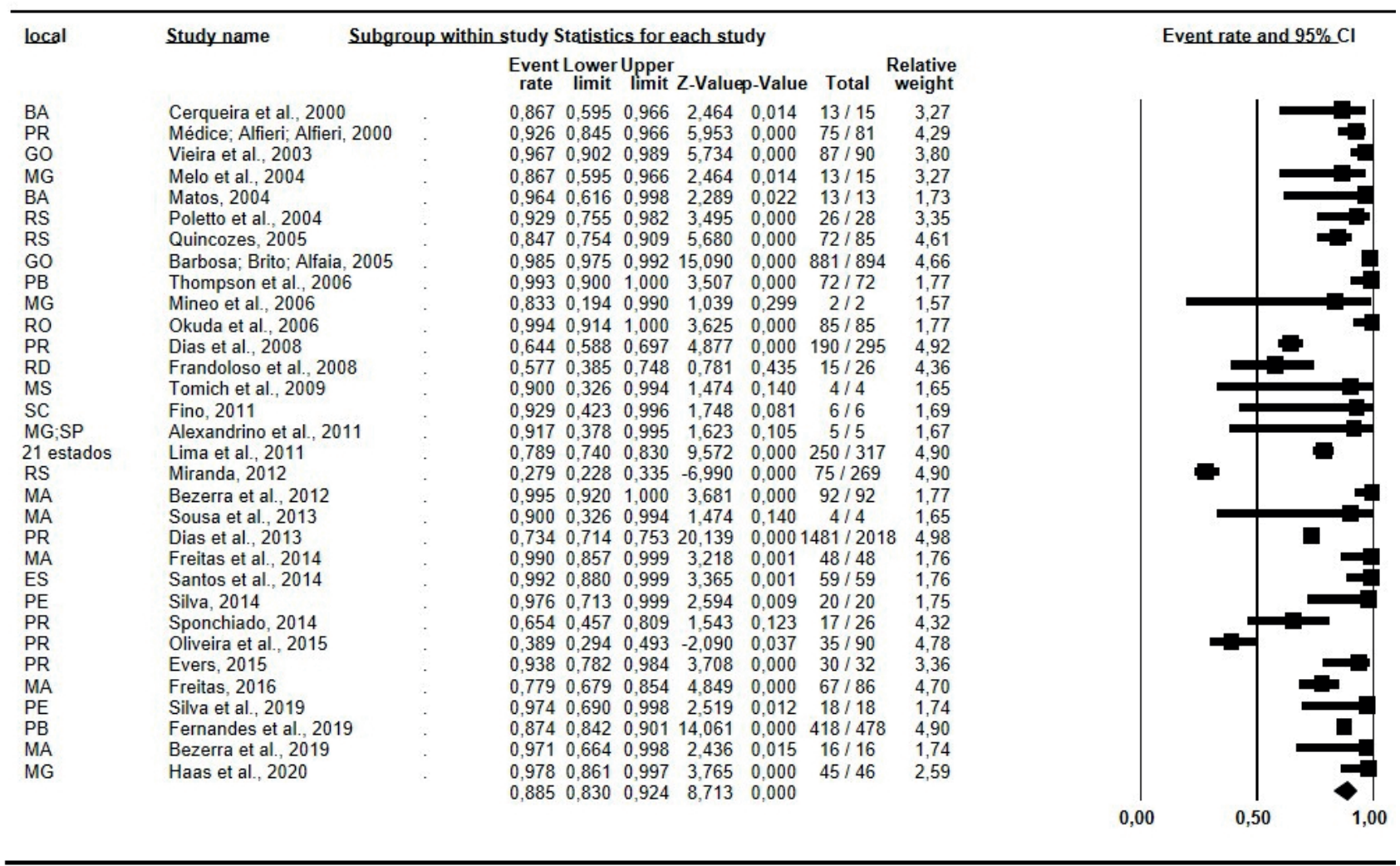

Figure 5. Prevalence of Bovine alphaherpesvirus 1 infection in cattle herds in Brazil.

To calculate the costs associated with abortion, the model adopted by Reichel et al. (2013) was considered, and for the replacement of dairy cows, the average value of a pregnant cow (US\$1,000) was subtracted from the value of an animal with the same score (considering the average of $450 \mathrm{~kg}$ of live weight) sold for slaughter (US\$750), which equates to a cost of US\$250 per abortion in dairy animals. To calculate the cost of abortion in beef animals, the replacement price of a weaned calf was calculated as $165 \mathrm{~kg}$ (US\$ 458) less than the slaughter value of an animal of the same weight (US\$286), which resulted in a loss of $\$ 172$ per abortion. For the calculation basis, the variations in the price of the ox's arroba, the replacement price of calves, and the average value of pregnant cows in December 2020 were used as a reference through the market quotation available in advertisements and national databases.

According to the IBGE (2017), $11,506,788$ dairy cows were milked in Brazil. Subtracted from the total number of animals of reproductive age in the national territory for the same year, it has $48,163,688$ heads of beef cows of reproductive age. Applying these values to the previous formula, we have: NBoAHV1 (dairy cattle $)=(n(v+n o v)) \times \operatorname{Pr} \times \operatorname{Pv} \times$ $\mathrm{Mb} \times \mathrm{PS} \times \mathrm{SV}=49,902$

NBoAHV1 (beef cattle) = NBoAHV1 -

NBoAHV1 (dairy cattle) $=208,877$ 
The estimate of the economic impact caused by abortion attributed to BoAHV1 for the different categories can be defined as follows:

$$
\begin{aligned}
& \text { NBoAHV1 (dairy cattle) } \times \text { associated } \\
& \text { cost (dairy cattle) }=49,902 \times 250= \\
& \text { US } \$ 12,475,500.00 \\
& \text { NBoAHV1 (beef cattle) } \times \text { associated } \\
& \text { cost (beef cattle) }=208,877 \times 172=
\end{aligned}
$$

US $\$ 35,926,844.00$

Therefore, the economic impact of abortion owing to BoAHV1 infection in Brazil is on the order of US $\$ 48,402,244.00$, considering both categories of affected animals.

This study is the first meta-analysis of the global prevalence of BoAHV1 infection in cattle in Brazil; it is also the first study to propose a model for calculating the economic impact of abortion in cattle owing to BoAHV1 infections based on the application of epidemiological data associated with BoAHV1.

Due to the variation in prevalence data and the number of studies included, statistical tests to assess the heterogeneity of the studies were significant $(P<0.001)$. Therefore, to estimate the magnitude of the effect or the variety of effect estimates due to the heterogeneity, the $\mathrm{I}^{2}$ test was used, whose value was found $\mathrm{I}^{2}=94.47 \%$, indicating considerable heterogeneity of the included studies $\left(75 \% \leq \mathrm{I}^{2} \leq 100\right)$ according to Deeks et al. (2019). This is due to the wide variation in the distribution of BoAHV1 infection in cattle in Brazil.

At least one study from 14 different Brazilian states was included. In addition, one of the studies (M. S. Lima et al., 2011) contained data from eight other states, totaling 22 states covered in the survey. The prevalence of the included studies ranged from 9.3\% (Zardo, 2017) to $86.28 \%$ (Okuda et al., 2006) for animals and $27.88 \%$ (Miranda, 2012) to $100 \%$ for herds (Alexandrino et al., 2011; D. C. Bezerra et al., 2012; N. P. C. Bezerra et al., 2019; Fino, 2011; Freitas et al., 2014; Matos, 2004; Mineo et al., 2006; Okuda et al., 2006; Thompson et al., 2006; Tomich et al., 2009; Santos et al., 2014; B. P. Silva et al., 2019; Sousa et al., 2013). These data show that BoAHV1 is widely distributed in Brazilian herds, as can be confirmed through the meta-analysis of the included studies for herds and animals with $88.53 \%(95 \% \mathrm{Cl}$ : $82.97 \%-92.43 \%)$ and $54.21 \%(95 \% \mathrm{Cl}$ : $49.07 \%-59.26 \%)$, respectively, from 2000 to 2020.

The prevalence of BoAHV1 infections found in animals (54.21\%; 95\% Cl: $49.07 \%-$ $59.26 \%$ ), considering the $\mathrm{Cl}$, is following the prevalence values observed in studies by Alexandrino et al. (2011), A. C. V. C. Barbosa et al. (2005), Cerqueira et al. (2000), J. A. Dias et al. (2013), Pasqualotto et al. (2015), Piovesan et al. (2013), Queiroz-Castro et al. (2019), B. P. Silva et al. (2019) and Tomich et al. (2009). In a similar study that determined the prevalence of BoAHV1 infection in China through a systematic review with meta-analysis, Chen et al. (2018) identified a prevalence of $40.0 \%$ in cattle from that country from 41 selected manuscripts with a total sample of 43,441 cattle. Together, the animals sampled from eligible manuscripts totaled 67,498 bovines to compose the meta-analysis of this study. It is noted that the impact in Brazil, verified by the data of higher prevalence, larger number of studies, and larger population of sampled cattle, is greater than the data pointed out in the study by Chen et al. (2018). Considering 
the size of the national herd associated with the higher prevalence of BoAHV1 infections in Brazil compared to the study by Chen et al. (2018), the economic and productive consequences are further deepened, especially since cattle raising is a commodity and China is a commercial partner and direct consumer of beef produced in Brazil.

The prevalence of infection in herds (88.53\%; 95\%Cl: $82.97 \%$ - 92.43\%) is in agreement with the findings of Cerqueira et al. (2000), L. G. Fernandes et al. (2019), Melo et al. (2004) and Quincozes (2005). The number of studies that showed a higher prevalence of herds compared to that found in this meta-analysis is associated with a great predominance of positive herds. Given that the median prevalence is $96.66 \%$, this high value and its proximity to the indicated values of prevalence per herd strengthens the evidence that BoAHV1 is widely distributed in herds since more than half of the studies point to a prevalence higher than that found in the present study.

Egger's test indicated no bias for prevalence studies in the animal population $(P>0.05)$, and the funnel graph (Figure 2) showed a symmetrical distribution of the included studies, with their predominance at the apex which indicated a smaller standard error of the selected manuscripts. The absence of bias in studies on the prevalence of infection in animals is because prevalence and risk factor surveys consider animals as sampling units when herds are the most assertive parameter for the analysis of risk factors due to the specificity of each property, such as reproductive, sanitary, and feeding management particular to each one.
The same was not observed when applied to the calculation to obtain the prevalence in herds $(P<0.05)$. This can be attributed to the fact that when considering the properties as sampling units, the minimum number of herds required to compose a prevalence study, with $5 \%$ error and $95 \% \mathrm{Cl}$ in an infinite population, would be approximately 400. Of the 32 studies considered to calculate the prevalence of herds, 26 sampled less than 100 properties, with a median of 47 and a range from 2 to 2018 herds sampled per study. Therefore, considering 100 properties as a minimum " $n$ " sample, 5\% error, and 95\% $\mathrm{Cl}$, each study should be carried out in a population of up to 134 properties per state or region studied, which explains the bias detected by the Egger test to calculate the prevalence of BoAHV1 in herds. In Figure 3, the presence of bias is verified by the asymmetry in the funnel graph, where some studies can be observed displaced out of the axis and closer to the base, showing a high standard error according to Begg and Berlin (1988).

Based on the parameters of prevalence, the number of animals at risk in the country, morbidity, period of susceptibility, and viral subtypes of BoAHV1 that are more closely related to abortion and reproductive parameters, were projected 258,779 abortions and an economic impact on livestock of US\$ $48,402,244.00$. This value is related to loss to the detriment of abortion related to BoAHV1 infections is below the values pointed out by Reichel et al. (2013), who reported an annual loss of US\$152.3 million from abortions related to Neospora caninum infections.

These values are subject to fluctuations due to variations in the price of animals in different regions of the country. It is important 
to highlight that the economic impact mentioned here concerns the direct losses related to the occurrence of abortion and the expenses associated with the replacement of animals in these cases. Considering that indirect losses also occur due to negative impacts on growth and reproduction (Biswas et al., 2013) and other forms of presentation of herpetic infections, such as respiratory, ocular, neurological, genital, and reproductive (Junqueira \& Alfieri, 2006; Nandi et al., 2009), it is inferred that the values presented here represent only a part of a higher cost.

According to Can, Ataseven and Yalçin (2016), significant changes in production and performance can also occur in infected cows, even if they do not show clinical signs or reproductive problems, which reinforces that the losses caused are high when considering only abortion as a single nosological entity. According to the authors, costs related to losses not associated with abortion characterized by decreased milk production (US\$177) and animal weight (US\$154), represent $65.0 \%$ (US\$331) of the total costs related to cases where abortion occured. Hage et al. (1998) indicated a statistically significant association between animals infected with BoAHV1 and a drop in milk production during the first 14 days of infection. Van Schaik et al. (1999) found that during an outbreak caused by BoAHV1, there was a drop in the production by $0.92 \mathrm{~kg}$ per animal per day for 9 weeks. According to Statham et al. (2015), estimated losses due to decreased production reach $1,000 \mathrm{~kg}$ of milk per lactation in seropositive animals compared to seronegative animals. According to Can et al. (2016), considering the probability of abortion, infection with BoAHV1 causes an impact of US\$ 379 per infected animal.
The values budgeted in this study provide a basal estimate of the economic and sanitary impacts caused by direct losses (abortion) associated with BoAHV1 infection in cattle in Brazil. Energetic actions related to appropriate sanitary measures should be carried out in the planning of preventive strategies with regard not only to BoAHV1 infection but also to other reproductive diseases of an infectious nature, such as the institution of sanitary prevention and control programs by the agencies of inspection and animal health protection. Regarding BoAHV1, the production of educational pamphlets, the delivery of lectures, radio advertisements, and other means of communication are good means of informing producers about the economic impacts, risks, and the need to adopt appropriate sanitary measures. In addition to health education actions, the institution of restrictive measures for animal transit and trade, such as the requirement of vaccination certificates for cattle, are necessary.

It is noteworthy that the results estimated in this study do not represent the totality of the impacts caused by herpetic infections in cattle in Brazil when considering only direct measurement losses, such as abortion. Nevertheless, beyond national borders, European Union countries have directed efforts toward the control and eradication of BoAHV1 infection since the 1980s (Ackermann \& Engels, 2006), and considering the customs protection mechanisms that can be adopted by economy and defense countries are consolidated, BoAHV1 infections can constitute an obstacle, in the near future, to the trade of animals of national origin, causing possible embargoes on cattle raising. 


\section{Conclusion}

Analogous to biology, BoAHV1 infections are a latent problem concerning sanitary strategies to contain the agent, while at the same time representing a cost for producers, from small to large, who need attention in planning and maintenance of a production system. Therefore, it can be concluded that BoAHV1 is widely disseminated in national herds, as can be seen from the numbers presented by different studies, silently causing significant economic, productive, and social impacts on Brazilian producers.

It is essential for the prophylaxis of infection by BoAHV1 to implement a program in the form of normative instruction, which covers educational campaigns on the risk of infection to the requirement of a vaccination certificate for trade and animal transit in the national territory. In addition, information about the economic impacts and health risks associated with infectious reproductive diseases in cattle needs to reach the producer so that a change in the national scenario can materialize in the medium-to-long-term. For this, animal health defense agencies and higher education institutions are essential for the planning, assistance, education, and inspection of adequate prophylactic measures to promote good health in national bovine herds.

\section{References}

Ackermann, M., \& Engels, M. (2006). Pro and contra IBR-eradication. Veterinary Microbiology, 113(3-4), 293-302. doi: 10. 1016/j.vetmic.2005.11.043
Ackermann, M., Belak, S., Bitsch, V., Edwards, S., Moussa, A., Rockborn, G., \& Thiry, E. (1990). Round table on infectious bovine rhinotracheitis/ infectious pustular vulvovaginitis virus infection diagnosis and control. Veterinary Microbiology, 23(1-4), 361-363. doi: 10.1016/03781135(90)90167-T

Afonso, I. B., Amoril, J. G., Alexandrino, B., Buzinaro, M. G., Medeiros, A. S. R., \& Samara, S. I. (2010) Anticorpos contra o herpesvírus bovino tipo 1 (BoHV-1) nas dez regiões de planejamento do estado de Goiás, Brasil. Ciência Animal Brasileira, 11(4), 892-898. doi: 10.5216/ cab.v11i4.6318

Alexandrino, B., Dias, F. C., Oliveira, M. C., Affonso, I. B., Pereira, G. T., \& Samara, S. I. (2011) Herpesvirus bovino associado à diarreia viral bovina e à leucose enzoótica bovina. Ars Veterinaria, 27(3), 168-174. doi: $\quad 10.15361 / 2175-0106.2011 v 27 n 3 p$ 168-174

Alice, F. J. (1978). Isolamento do vírus da rinotraqueíte infecciosa bovina (IBR) no Brasil. Revista Brasileira de Biologia, 38(4), 919-920.

Arruda, E. F., Silva, T. I. B., Aragão, B. B., Castro, R. S., \& Gomes, Y. A. (2019). Soroprevalence of bovine alphaherpesvirus type 1 (BoHV1) and risk factors associated with dairy properties of the municipality of Senador Guiomard, Acre, Brazil. Arquivos do Instituto Biológico, 86(e1362018), 1-6. doi: 10.1590/ 1808-1657001362018

Ata, A., Kocamüftüoğlu, M., Hasircioğlu, S., Kale, M., \& Ğülay, M. Ş. (2012). Investigation of relationship between bovine herpesvirus-1 (BHV-1) infection and fertility in repeat breeding dairy 
cows in family-type small dairy farms. Kafkas Üniversitesi Veteriner Fakültesi Dergisi, 18(4), 579-583. doi: 10.9775/ kvfd.2011.5893

Barbosa, A. C. V. C., Brito, W. M. E. D., \& Alfaia, B. T. (2005). Soroprevalência e fatores de risco para a infecção pelo herpesvírus bovino tipo 1 (BHV-1) no Estado de Goiás, Brasil. Ciência Rural, 35(6), 1368-1373. doi: 10.1590/S0103-84782005000600022

Barbosa, V. M., Gondim, C. C., Nasciutti, N. R., Oliveira, P. M., Alfieri, A. A., Fritzen, J. T. T.,... Saut, J. P. E. (2019). Risk factors associated with viral infections (BoHV-1 and BVDV) in crossbreed dairy herds with reproductive failures, Uberlândia, MG. Arquivo Brasileiro de Medicina Veterinaria e Zootecnia, 71(4), 1243-1250. doi: 10. 1590/1678-4162-10326

Becker, A. S., Rodrigues, M. G., Orlandin, J. R., Menezes, P. Q., Matos, C. A., Wilsmann, D. E.,... Rodrigues, P. R. C. (2015). Anticorpos neutralizantes contra o herpesvírus bovino tipo 1 e o vírus da diarréia viral bovina em bovinos vacinados e não vacinados da região sul do estado do Rio Grande do Sul. Science and Animal Health, 3(2), 209-220. doi: 10.15210/sah. v3i2.5610

Begg, C. B., \& Berlin, J. A. (1988). Publication bias: a problem in interpreting medical data. Journal of the Royal Statistical Society. Series A, 151(3), 419-463. doi: $10.2307 / 2982993$

Bennett, R. (2003). The 'direct costs'of livestock disease: the development of a system of models for the analysis of 30 endemic livestock diseases in Great Britain. Journal of Agricultural Economics, 54(1), 55-71. doi: 10.1111/j.1477-9552.2003.tb00048.x
Bezerra, D. C., Chaves, N. P., Sousa, V. E., Santos, H. P., \& Pereira, H. M. (2012). Fatores de risco associados à infecção pelo Herpesvírus Bovino Tipo $1 \mathrm{em}$ rebanhos bovinos leiteiros da região Amazônica maranhense. Arquivos do Instituto Biológico, 79(1), 107-111.

Bezerra, N. P. C., Bezerra, D. C., Santos, H. P., Pereira, H. M., \& Silva, A. L. A. (2019). Risk factors analysis applied to antibodies to Bovine Herpesvirus Type 1, Bovine Viral Diarrhea Virus, Bovine Leukemia Virus and Brucella abortus among cattle: A cross-sectional study. Acta Veterinaria Brasilica, 13(1), 5-12. doi: 10.21708/avb. 2019.13.1.7818

Biswas, S., Bandyopadhyay, S., Dimri, U., \& Patra, P. H. (2013). Bovine herpes virus-1 (BHV-1) - a re-emerging concern in livestock: a revisit to its biology, epidemiology, diagnosis and prophylaxis. Veterinary Quarterly, 33(2), 68-81. doi: 10.1080/01652176.2013.799301

Campos, F. S., Franco, A. C., Hübner, S. O., Oliveira, M. T., Silva, A. D., Esteves, P. A.,... Rijsewijk, F. A. M. (2009). High prevalence of co-infections with bovine herpesvirus 1 and 5 found in cattle in southern Brazil. Veterinary Microbiology, 139(1-2), 67-73. doi: 10.1016/j.vetmic.2009.05.015

Can, M. F., Ataseven, V. S., \& Yalçin, C. (2016). Estimation of production and reproductive performance losses in dairy cattle due to bovine herpesvirus 1 (BoHV-1) infection. Veterinarski Arhiv, 86(4), 499-513.

Cerqueira, R. B., Carminati, R., Silva, J. M., Soares, G. C., Meyer, R., \& Sardi, S. (2000). Serological survey for bovine herpesvirus 1 in cattle from different regions in the state of Bahia, Brazil. Brazilian Journal of 
Veterinary Research and Animal Science, 37(6), 497-500. doi: 10.1590/S1413-9596 2000000600014

Chen, X., Wang,X., Qi, Y., Wen, X., Li, C., Liu, X., \&Ni, H. (2018). Meta-analysis of prevalence of bovine herpes virus 1 in cattle in Mainland China. Acta Tropica, $187\left(\mathrm{n}^{\circ}\right), 37-43$. doi: 10.1016/j.actatropica.2018.07.024

Constable, P. D., Hinchcliff, K. W., Done, S. H., \& Grünberg, W. (2021). Clínica veterinária: um tratado de doenças dos bovinos, ovinos, suínos e caprinos. Rio de Janeiro: Guanabara Koogan.

Deeks, J. J., Higgins, J. P. T., \& Altman, D. G. (2019). Chapter 10: Analysing data and undertaking meta-analyses. In J. P. T. Higgins, J. Thomas, J. Chandler, M. Cumpston, T. Li, M. J. Page, \& V. A. Welch (Eds.), Cochrane handbook for systematic reviews of interventions version 6.1 (updated September 2020). Chichester (UK): John Wiley \& Sons. Retrieved from https://training.cochrane.org/handbook/ current/chapter-10

Dias, J. A., Alfieri, A. A., Ferreira-Neto, J. S., Gonçalves, V. S. P., \& Müller, E. E. (2013). Seroprevalence and risk factors of bovine herpesvirus 1 infection in cattle herds in the State of Paraná, Brazil. Transboundary and Emerging Diseases, 60(1), 39-47. doi: 10.1111/j.1865-1682.2012.01316.x

Dias, J. A., Alfieri, A. A., Médici, K. C., Freitas, J. C., Ferreira, J. S., Neto, \& Müller, E. E. (2008). Risk factors for bovine herpesvirus 1 infection in cattle herds in the West region of Parana State. Pesquisa Veterinaria Brasileira, 28(3), 161-168. doi: 10.1590/ s0100-736X2008000300006
Dias, M. M. (2006). Análise da soroprevalência do herpesvírus bovino tipo 1 e do cortisol sérico em diferentes situações de manejo no Rio Grande do Sul. Tese de doutorado, Universidade Federal do Rio Grande do Sul, Porto Alegre, RS, Brasil.

Evers, F. (2015). Soroepidemiologia de agentes associados às doenças reprodutivas em bovinos leiteiros do noroeste do estado do Paraná. Tese de doutorado, Universidade Estadual de Londrina, Londrina, PR, Brasil.

Fernandes, L. A. M., Figueredo, V. C. S., Bezerra, A. R. A., Murta, D. C. R. X., Murta, D. V. F., Souza, R. B.,... Barbosa, L. K. G. (2019b). Taxa de prenhez em vacas leiteiras com uso de programa de IATF na região Norte de Minas Gerais. Brazilian Journal of Development, 5(11), 24811-24815. doi: 10.34117/bjdv5n11-161

Fernandes, L. G., Denwood, M. J., Santos, C. S. A. B., Alves, C. J., Pituco, E. M., Romaldini, A. H. C. N.,... Azevedo, S. S. (2019a). Bayesian estimation of herd-level prevalence and risk factors associated with BoHV-1 infection in cattle herds in the State of Paraíba, Brazil. Preventive Veterinary Medicine, 169, (104705), 1-7. doi: 10.1016/j.prevetmed.2019.104705

Fino, T. C. M. (2011). Anticorpos contra herpesvírus bovino tipo 1 (HVB-1) e vírus da diarréia bovina a vírus (BVDV) em rebanhos da raça Crioula Lageana no Planalto Catarinense. Dissertação de mestrado, Faculdade de Agronomia e Medicina Veterinária, Universidade de Brasília, Brasília, DF, Brasil.

Flores, E. F. (2017). Virologia veterinária: virologia geral e doenças víricas (3a ed.). Santa Maria: UFSM. 
Frandoloso, R., Anziliero, D., Spagnolo, J., Kuse, N., Fiori, C., Scortegagna, G. T.,... Kreutz, L. C. (2008). Prevalência de leucose enzoótica bovina, diarreia viral bovina, rinotraqueíte infecciosa bovina e neosporose bovina em 26 propriedades leiteiras da região nordeste do Rio Grande do Sul, Brasil. Ciência Animal Brasileira, 9(4), 1102-1106.

Freitas, E. J. P. (2016). Características epidemiológicas da infecção de bovinos jovens de corte, em rebanhos com alto trânsito animal, para BoHV-1, BVDV, BTV e Leptospira spp. no Estado do Maranhão. Tese de doutorado, Universidade Federal de Minas Gerais, Belo Horizonte, MG, Brasil.

Freitas, E. J. P., Lopes, C. E. R., Moura, J. M., Fo., Sá, J. S., Santos, H. P., \& Pereira, H. M. (2014). Frequência de anticorpos contra o herpesvírus bovino tipo 1 (BoHV-1) em bovinos de corte não vacinados. Semina: Ciências Agrárias, 35(3), 1301-1310. doi: 10.5433/1679-0359.2014v35n3p1301

Galvão, C. L., Doria, J. D., \& Alice, F. J. (1962/1963). Anticorpos neutralizantes para o vírus da rinotraqueíte infecciosa dos bovinos, em bovinos do Brasil. Boletim do Instituto Biológico da Bahia, 6(1), 15-25.

Graham, D. A. (2013). Bovine herpes vírus-1 (BoHV-1) in cattle-a reviewwith emphasis on reproductive impacts and the emergence of infection in Ireland and the United Kingdom. Irish Veterinary Journal, 66(1), 14. doi: 10.1186/2046-0481-66-15

Haas, D. J., Barbieri, J. M., Freitas, E. J. P., Oliveira, M. S., Porto, B. R., Rodrigeus, R. O.,... Lage, A. P. (2020). Seroprevalence and intercurrence of reproductive pathogens in cattle from family farms in North of Minas Gerais, Brazil. Semina: Ciencias Agrarias, 41(1), 145-158. doi: 10.5433/1679-0359.2020v41n1p145

Hage, J. J., Schukken, Y. H., Dijkstra, T. H., Barkema, H. W., Van Valkengoed, P. H. R., \& Wentik, G. H. (1998). Milk production and reproduction during a subclinical bovine herpesvirus 1 infection on a dairy farm. Preventive Veterinary Medicine, 34(2-3), 97-106. doi: 10.1016/S0167-58 77(97)00088-3

Holz, C. L., Cibulski, S. P., Teixeira, T. F., Batista, H. B. C. R., Campos, F. S., Silva, F. S.,... Roehe, P. M. (2009). Seroprevalence of bovine herpesvirus types 1 and/or 5 in the state of Rio Grande do Sul. Pesquisa Veterinaria Brasileira, 29(9), 767-773. doi: 10.1590/S0100-736X2009000900014

Instituto Brasileiro de Geografia e Estatística (2017). Censo Agropecuário 2017: SIDRA: Sistema IBGE de Recuperação Automática. Retrieved from https:// sidra.ibge.gov.br/pesquisa/censoagropecuario/censo-agropecuario-2017.

Junqueira, J. R. C., \& Alfieri, A. A. (2006). Falhas na reprodução na pecuária bovina de corte com ênfase para as causas infecciosas. Semina: Ciências Agrárias, 27(2), 289-298. doi: 10.5433/1679-0359. 2006v27n2p289

Junquiera, J. R. C., Freitas, J. C., Alfieri, A. F., \& Alfieri, A. A. (2006). Avaliação do desempenho reprodutivo de um rebanho bovino de corte naturalmente infectado com BoHV-1, BVDV e Leptospira hardjo. Semina: Ciências Agrárias, 27(3), 471-480. doi:10.5433/1679-0359.2006v27n3p471 
Lima, F. A. B. (2017). Infecção pelo alphaherpesvírus bovino tipo 1, vírus da diarreia viral bovina e Brucella abortus em fêmeas bovinas de corte abatidas em um frigorífico sob SIF no estado do Maranhão. Dissertação de mestrado, Universidade Estadual do Maranhão, São Luís, MA, Brasil.

Lima, M. S., Nogueira, A. H. C., Okuda, L. H., Stefano, E., \& Pituco, E. M. (2011). Pesquisa de anticorpos contra o herpesvírus bovino tipo 1 em bovinos no Brasil. Biológico, 73(2), 214-218.

Lovato, L. T., Weiblen, R., Tobias, F. L., \& Moraes, M. P. (1995). Herpesvírus bovino tipo 1 (HVB 1): inquérito soro-epidemiológico no rebanho leiteiro do estado do Rio Grande do Sul, Brasil. Ciência Rural, 25(3), 425-430. doi: 10.1590/S0103-84 781995000300017

Macías-Rioseco, M., Silveira, C., Fraga, M., Casaux, L., Cabrera, A., Francia, M. E.,... Riet-Correa, F. (2020). Causes of abortion in dairy cattle in Uruguay. Pesquisa Veterinária Brasileira, 40(5), 325-332. doi: 10.1590/1678-5150-PVB-6550

Matos, P. F. (2004). Rinotraqueíte infecciosa dos bovinos/vulvovaginite pustulosa infecciosa (IBR/IPV): prevalência e incidência em bovinos leiteiros criados em cinco microregiões no Estado da Bahia. Tese de doutorado, Universidade de São Paulo, São Paulo, SP, Brasil.

Médici, K. C., Alfieri, A. A., \& Alfieri, A. F. (2000). Prevalência de anticorpos neutralizantes contra o herpesvírus bovino tipo 1, decorrente de infecção natural, em rebanhos com distúrbios reprodutivos. Ciência Rural, 30(2), 347-350. doi: 10. 1590/S0103-84782000000200025
Melo, C. B., Leite, R. C., Lobato, Z. I. P., \& Leite, R. C. (2004). Infection by Neospora caninum associated with bovine herpesvirus 1 and bovine viral diarrhea virus in cattle from Minas Gerais State, Brazil. Veterinary Parasitology, 119(2-3), 97-105. doi: 10.10 16/j.vetpar.2003.12.002

Melo, C. B., Lobato, Z. I. P., Camargos, M. F., Souza, G. N., Martins, N. R. S., \& Leite, R. C. (2002). Distribuição de anticorpos para herpesvírus 1 em rebanhos bovinos. Arquivo Brasileiro de Medicina Veterinária e Zootecnia, 54(6), 575-580. doi: 10.1590/ S0102-09352002000600003

Mendes, M. B., Bittar, J. F. F., Pereira, W. A. B., Arduino, G. G C., Bittar, E. R., Panetto, J. C. C., \& Santos, J. J. (2009). Determinação da prevalência das principais doenças da reprodução no rebanho bovino da região de Uberaba-MG. Ciência Animal Brasileira, (Suppl. 1), 772-777.

Mineo, T. W., Alenius, S., Näslund, K., Montassier, H. J., \& Björkman, C. (2006). Distribution of antibodies against Neospora caninum, BVDV and BHV-1 among cows in brazilian dairy herds with reproductive disorders. Revista Brasileira de Parasitologia Veterinária, 15(4), 188-192.

Miranda, I. C. S. (2012). Fatores Associados à Infecção pelo vírus da diarreia viral bovina e pelo herpesvírus bovino tipo 1 em rebanhos leiteiros da Mesorregião Centro-Oriental do Rio Grande do Sul. Dissertação de mestrado, Universidade Federal do Rio Grande do Sul, Porto Alegre, RS, Brasil.

Moher, D., Liberati, A., Tetzlaff, J., \& Altman, D. G. (2009). Preferred reporting items for systematic reviews and meta-analyses: the PRISMA statement. PLoS Medicine, 
6(7), e1000097. doi: 10.1371/journal.pm ed.1000097

Nandi, S., Kumar, M., Manohar, M., \& Chauhan, R. S. (2009). Bovine herpes virus infections in cattle. Animal Health Research Reviews, 10(1), 85-98. doi: 10.1017/S146 6252309990028

Okuda, L. H., Aguiar, D. M., Cavalcante, G. T., Stefano, E., Del Fava, C., Pituco, E. M.,... Gennari, S. M. (2006). Inquérito soro-epidemiológico do herpesvírus bovino tipo 1 (BoHV-1) no município de Montenegro, estado de Rondônia, Brasil. Biológico, 68(Suppl.), 157-159.

Oliveira, R. A. M., Lorenzetti, E., Alfieri, A. A., \& Lisbôa, J. A. N. (2015). Prevalence of latent infection with BoHV-1 and BoHV-5 in beef cattle of Parana, Brazil. Arquivo Brasileiro de Medicina Veterinaria e Zootecnia, 67(5), 1217-1225. doi: 10.1590/1678-41 $62-7496$

Pasqualotto, W., Sehnem, S., \& Winck, C A. (2015). Incidência de rinotraqueíte infecciosa bovina (IBR), diarreia viral bovina (BVD) e leptospirose em bovinos leiteiros da região oeste de Santa Catarina - Brasil. Revista em Agronegócio e Meio Ambiente, 8(2), 249270. doi: $10.17765 / 2176-9168.2015 v 8 n$ 2p249-270

Pereira, E. C. M. (2011). Detecção sorológica e molecular do herpesvírus bovino $1 \mathrm{em}$ estruturas ovarianas de fêmeas bovinas. Dissertação de mestrado, Universidade Federal de Viçosa, Viçosa, MG, Brasil.

Pereira, E. T. N., Freitas, F. E., Neto, Cordeiro, A. L. S., Silva, L. M. T., \& Figueiredo, Y. N. (2020). Avaliação do escore de cio e sua influência na taxa de concepção em vacas nelore no norte de Minas Gerais. Revista de Educação, Ciência e Tecnologia de Almenara, 2(3), 32-45. doi: 10.46636/ recital.v2i3.129

Pereira, P. A. C., Ferreira, A. M., Carvalho, L. B., Verneque, R. S., Henry, M., \& Leite, R. C. (2013). Comparação dos índices de eficiência reprodutiva por diferentes métodos em rebanhos bovinos leiteiros. Arquivo Brasileiro de Medicina Veterinária e Zootecnia, 65(5), 1383-1388. doi: 10.15 90/S0102-09352 013000500016

Piovesan, M., Fernandes, M. H. V., Corrêa, R. A., Prado, M. H. J., Camargo, A. D., \& Rodrigues, P. R. C. (2013). Anticorpos contra o herpesvírus bovino tipo 1, vírus da diarreia viral bovina e vírus da leucose enzoótica bovina na Região da Campanha do estado do Rio Grande do Sul. Science and Animal Health, 1(1), 38-49. doi: 10. 15210/sah.v1i1.2609

Pituco, E. M. (1988). Ocorrência da rinotraqueíte infecciosa dos bovinos/ vulvovaginite pustular infecciosa (IBR/ IPV) em rebanhos bovinos criados nos estados de São Paulo, Rio Grande do Sul, Paraná e Minas Gerais. Dissertação de mestrado, Faculdade de Medicina Veterinária e Zootecnia, Universidade de São Paulo, São Paulo, SP, Brasil.

Poletto, R., Kreutz, L. C., Gonzales, J. C., \& Barcellos, L. J. G. (2004). Prevalência de tuberculose, brucelose e infecções víricas em bovinos leiteiros do municípios de Passo Fundo, RS. Ciência Rural, 34(2), 595-598. doi: 10.1590/S0103-84 782004000200043 
Queiroz-Castro, V. L. D., Costa, E. P., Alves, S. V. P., Guimarães, J. D., Dohanik, V. T., Santos, M. R.,... Silva, A., Jr. (2019). Detection of bovine herpesvirus 1 in genital organs of naturally infected cows. Theriogenology, 130, 125-129. doi: 10. 1016/j.theriogenology.2019.03.003

Quincozes, C. G. (2005). Prevalência e fatores de risco associados às infecções pelos herpesvírus bovino tipo 1 e 5 (BHV-1 e 5) e pelo vírus da diarréia viral bovina (BVDV) nos rebanhos dos municípios de Santa Vitória do Palmar e Chuí. Dissertação de mestrado, Faculdade de Veterinária, Universidade Federal de Pelotas, Pelotas, RS, Brasil.

Ran, X., Chen, X., Ma, L., Wen, X., Zhai, J., Wang, M.,... Ni, H. (2019). A systematic review and meta-analysis of the epidemiology of bovine viral diarrhea virus (BVDV) infection in dairy cattle in China. Acta Tropica, 190, 296-303. doi: 10.1016/j. actatropica.2018.08.031

Reichel, M. P., Ayanegui-Alcérrea, M. A., Gondim, L. F. P., \& Ellis, J. T. (2013). What is the global economic impact of Neospora caninum in cattle - The billion dollar question. International Journal for Parasitology, 43(2), 133-142. doi: 10. 1016/j.ijpara.2012.10.022

Rosa, C. O., Morotti, F, Bonato, D. V., Souza, A. K., Silva, C. B., Diniz, L. T., \& Seneda, M. M. (2017). Comparação da taxa de concepção com a utilização ou não de um potencializador de sêmen na inseminação artificial em tempo fixo em bovinos. Revista Acadêmica Ciência Animal, 15(Suppl. 2), 331-332. doi: 10.7213/ cienciaanimal.v15iSuppl\%202.17412
Santos, M. R., Ferreira, H. C. C., Santos, M. A., Saraiva, G. L., Tafuri, N. F., Santos, G. M.,... Silva, A., Jr. (2014). Antibodies against bovine herpesvirus 1 in dairy herds in the state of Espirito Santo, Brasil. Revista Ceres, 61(2), 280-283. doi: 10.1590/S0 034-737X2014000200017

Sayers, R. G. (2017). Associations between exposure to bovine herpesvirus 1 (BoHV1) and milk production, reproductive performance, and mortality in Irish dairy herds. Journal of Dairy Science, 100(2), 1340-1352. doi: 10.3168/jds.2016-11113

Silva, B. P., Soares, L. B. F., Macêdo, A. A., Oliveira, J. M. B., Aragão, B. B., Nascimento, S. A., \& Pinheiro, J. W., Jr. (2019). Seroprevalence and risk factors for bovine herpesvirus type 1 and occurrence of bovine viral diarrhea virus infections in dairy cows in Pernambuco. Medicina Veterinaria (Brazil), 13(3), 399-405. doi: 10.26605/medvetv13n3-3302

Silva, F. S., Oliveira, J. M. B., Batista, A. F. B., Fo., Ribeiro, C. P., Pituco, E. M., \& Pinheiro, J. W., Jr. (2015). Análise epidemiológica da infecção pelo herpesvírus bovino tipo 1 (BoHV-1) em bovinos no Estado de Pernambuco. Acta Scientiae Veterinarie, 43, (1324), 1-11.

Silva, M. C. O. P. (2011). Soroprevalência do herpesvirus bovino tipo 1 e 5 no estado de São Paulo, Brasil. Dissertação de mestrado, Instituto Biológico, São Paulo, SP, Brasil.

Sousa, V. E., Bezerra, D. C., Chaves, N. P., Santos, H. P., \& Pereira, H. M. (2013). Frequência de anticorpos e fatores de risco associados à infecção pelo vírus da diarreia viral bovina (BVDV) e herpesvírus bovino tipo 
1 (BoHV-1) em fêmeas bovinas leiteiras criadas em sistema de produção semiintensivo. Revista Brasileira de Medicina Veterinária, 35(1), 21-25.

Sponchiado, D. (2014). Prevalência dos principais vírus respiratórios em bovinos da raça holandesa, no estado do Paraná. Tese de doutorado, Universidade Estadual Paulista Júlio de Mesquita Filho, Faculdade de Medicina Veterinária e Zootecnia, Botucatu, SP, Brasil.

Statham, J. M., Randall, L. V., \& Archer, S. C. (2015). Reduction in daily milk yield associated with subclinical bovine herpesvirus 1 infection. Veterinary Record, 177(13), 339. doi: 10.1136/vr.103105

Thompson, J. A., Leite, R. M. H., Gonçalves, V. S. P., Leite, R. C., Bandeira, D. A., Herrmann, G. P.,... Page, A. P. (2006). Spatial hierarchical variances and age covariances for seroprevalence to Leptospira interrogans serovarhardjo, BoHV-1 andBVDV for cattle in the State of Paraíba, Brazil. Preventive Veterinary Medicine, 76(3-4), 290-301. doi: 10.1016/j.prevetmed.2006.05.010

Thrusfield, M. (2005). Veterinary epidemiology. Oxford: Blackwell Science Ltd.

Tomich, R. G. P., Serra, C. V., Bomfim, M. R. Q., Campos, F. S., Lobato, Z. I. P., Pellegrin, A. O.,... Barbosa-Stancioli, E. F. (2009). Reproductive diseases serosurvey in dairy cattle from rural settlements of corumbá city, mato grosso do sul state, Brazil. Arquivo Brasileiro de Medicina Veterinaria e Zootecnia, 61(4), 986-991. doi: 10.1590/ S0102-09352009000400029

Van Schaik, G., Shoukri, M., Martin, S. W., Schukken, Y. H., Nielen, M., Hage, J. J., \& Dijkhuizen, A. A. (1999). Modelling the effect of an outbreak of bovine herpesvirus type 1 on herd-level milk production of Dutch dairy farms. Journal of Dairy Science, 82(5), 944-952. doi: 10.3168/jds.S0022-0302(99)75313-0

Vaz, R. Z., \& Lobato, J. F. P. (2010). Efeito da idade de desmame no desempenho reprodutivo de novilhas de corte expostas à reprodução aos 13/15 meses de idade. Revista Brasileira de Zootecnia, 39(1), 142-150. doi: 10.1590/S1516-359 82010000100019

Vieira, S., Brito, W. M. E. D., Souza, W. J., Alfaia, B. T., \& Linhares, D. C. L. (2003). Anticorpos para o herpesvírus bovino 1 (BHV-1) em bovinos do estado de Goiás. Ciência Animal Brasileira, 4(2), 131-137.

Wathes, D. C., Oguejiofor, C. F., Thomas, C., \& Cheng, Z. (2020). Importance of viral disease in dairy cow fertility. Engineering, 6(1), 26-33. doi: 10.1016/j. eng.2019.07.020

World Organization for Animal Health (2008). Feeding the world better by controlling animal diseases. Editorials from the Director General. Retrieved from https://www.oie.int/index.php?id= 201\&tx_ttnews\%5Btt_news\%5D $=458 \& \mathrm{c}$ Hash=a54e062304\#: :text $=$ With $\% 20$ regard\%20to\%20livestock\%20produc tion,recent\%20years\%20is\%20now\%20 stabilising.

Zardo, R. (2017). Prevalência e variáveis associadas à infecção por BoHV-1, BVDV, Leptospira spp. e Neospora caninum em bovinos leiteiros no município de Novo Xingu-RS. Dissertação de mestrado, Faculdade de Veterinária, Universidade Federal de Pelotas, Pelotas, RS, Brasil. 
